\title{
Changes In The Carbon And Energy Balance Of The Sagebrush Steppe Ecosystem Of The Pacific Northwest
}

M.L.S. Chambers

K.L. Clawson

R.S. Inouye

November 2002

Idaho National Engineering and Environmental Laboratory Bechtel BWXT Idaho, LLC 


\title{
Changes In The Carbon And Energy Balance Of The Sagebrush Steppe Ecosystem Of The Pacific Northwest
}

\author{
M.L.S. Chambers - Idaho National Engineering and Environmental Laboratory \\ K.L. Clawson - NOAA/Field Research Division \\ R.S. Inouye - Idaho State University
}

November 2002

Idaho National Engineering and Environmental Laboratory

Idaho Falls, Idaho 83415

Prepared for the U.S. Department of Energy

Under DOE Idaho Operations Office

Contract DE-AC07-99ID13727 


\title{
Changes in the Carbon and Energy balance of the Sagebrush Steppe Ecosystem of the Pacific Northwest
}

\author{
M. L. S. Chambers ${ }^{1}$, K. L. Clawson ${ }^{2}$, R. S. Inouye ${ }^{3}$
}

${ }^{1}$ Idaho National Engineering and Environmental Laboratory, Idaho Falls, Idaho, ${ }^{2}$ NOAA/Field Research Division, Idaho Falls, ID, ${ }^{3}$ Idaho State University, Pocatello, ID

\section{SUMMARY}

We propose a multi-agency study to understand the impacts of land-use change on the carbon and energy balance of the Pacific Northwest. By integrating data for the carbon and energy fluxes across different scales within each land-use type, we will develop more accurate input parameters for the regional climate models. The product of this study will address two priorities recommended by the National Academy of Sciences; 1) reduce uncertainties in climate change projections and 2) provide a more definitive evaluation of long-term changes.
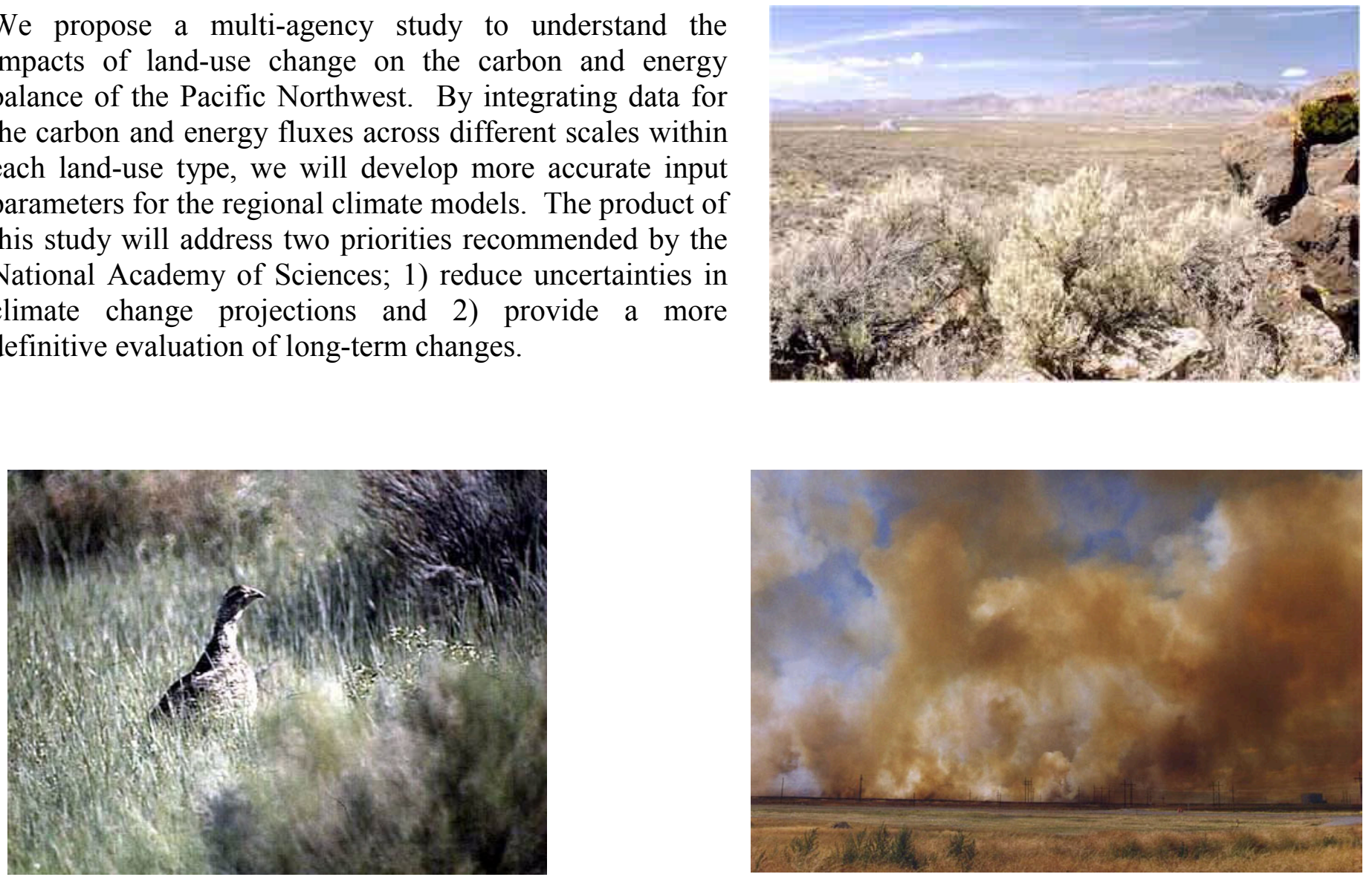

\section{BACKGROUND}

The sagebrush steppe is an endangered ecosystem (Noss et al., 1995), which covers approximately $4.5 \mathrm{X}$ $10^{7}$ hectares in the Columbia and Snake River Plateaus, the northern edge of the Great Basin, and southwestern Wyoming (West, 1983a). This fragile ecosystem is becoming more drought- and fire-prone, and is being invaded by exotic plants. It is a major habitat for some of the largest animals in the U.S. and is home to a sizeable and growing human population. The greatest impacts to the sagebrush steppe ecosystem have been brought about due to agriculture and livestock grazing. About 10\% of sagebrush steppe in this region has gone into agriculture and $99 \%$ of this ecosystem has been affected by livestock grazing with 30\% having been heavily grazed (Noss et al., 1995). A new NASA-funded study, currently 
underway, suggests that land-use change may have as important an impact on climate change as the greenhouse gases (http://www.gsfc.nasa.gov/topstory/archives.html). Although these factors clearly indicate the need to study this ecosystem relative to climate change issues, there has been little research (Angell et al., 2001). Much more is known about the carbon and energy balance in forests of the northeastern and southeastern U.S.

Acres of wheat, barley, and potatoes have altered the carbon cycle and the albedo of the sagebrush steppe ecosystem. Large amounts of water applied to these plants by way of irrigation have resulted in greater actual evapotranspiration. Areas that have been grazed are much more prone to invasion by exotic plant species, such as cheatgrass. Because cheatgrass matures in the early to mid-summer, during the fire season and because the cheatgrass has a higher fuel load, wildfires burn hotter and more rapidly when they occur. All these factors have impacted the water cycle, carbon cycle, and the energy balance of this region.

Although there is tremendous variation in climate in the Pacific Northwest, from the rain forests along the coast to the deserts on the eastern side of the Cascade Mountains, research conclusions are often inappropriately broad, encompassing all ecosystems that fall within this region. By the 2050s, temperature is expected to increase by $2.8^{\circ} \mathrm{C}$ and precipitation is expected to either increase by a range of 5 to $60 \%$ or decrease by $7 \%$, depending on which model projections are used (Jackson et al., 2001; Parson et al., 2001). Regional predictions of climate change need to be improved (MacDonald, 2001).

\section{OBJECTIVE}

This study will fill an information gap about carbon and energy dynamics in North American deserts. The current ecological studies on desert ecosystems are in warm deserts; are not examining the impacts of land-use change on carbon and energy fluxes; and/or are not studying undisturbed sagebrush stands (http://www.unlv.edu/Climate Change Research/; http://jornada-www.nmsu.edu/; L. Hipps, 2002). This study also addresses two priorities recommended by the National Academy of Sciences: 1) reduce the uncertainties in climate change projections by improving the understanding and modeling of factors that determine atmospheric concentrations of greenhouse gases and aerosols and of the so-called "feedbacks" that determine the sensitivity of the climate system to prescribed increases in greenhouse gases, 2) ensure the existence of a long-term monitoring system that will provide more definitive evaluation of decadal- to century-scale changes, including observations of key state variables and more comprehensive regional measurements of greenhouse gases (U.S. Climate Change Research Initiative: Survey of Research Strategies to Reduce Scientific Uncertainties, 2001).

\section{APPROACH}

Kirk Clawson, acting director of the local NOAA/Field Research Division (FRD) and Richard Inouye, a professor of ecology with Idaho State University (ISU), will collaborate with scientists at Idaho National Engineering and Environmental Laboratory (INEEL). The NOAA/FRD in Idaho Falls has expertise in the measuring and modeling of air-surface exchange from both towers and aircraft. Dr. Inouye is the director of the Center for Ecological Research and Education at ISU and has expertise in the biodiversity and anthropogenic impacts to the sagebrush steppe and wetlands. INEEL has expertise in ecology, geographical information systems (GIS), and atmospheric chemistry.

We will examine carbon sources and sinks at different scales in a mature sagebrush stand, a grazed area, and in cropland. In each land-use type, a study plot with three replicates will be set up near an eddy correlation flux tower. In the study plots, we will measure carbon dioxide $\left(\mathrm{CO}_{2}\right)$ fluxes of the soil and 
plants, soil temperature, soil moisture, and plant biomass. The flux tower will measure the net flux of $\mathrm{CO}_{2}$ to the atmosphere. The landscape scale carbon and energy balance will be estimated from aerial flux measurements made from an aircraft. Remotely sensed vegetation and evapotranspiration data will be interpreted to provide a gross picture of the energy balance. The flux data for each scale will be integrated according to land-use type to provide better input parameters of carbon and energy balance for the regional climate models. The operation of the eddy flux towers on a long-term basis will provide a more definitive evaluation of long-term changes in the carbon and energy balance.

The work will be conducted at the Idaho National Environmental Research Park, located on the Idaho National Engineering and Environmental Laboratory (INEEL) site, within the Great Basin/Snake River Plain, cold desert. This location makes an excellent study site for several reasons. The INEEL is located at the western edge of the upper Snake River Plain, 50 miles west of Idaho Falls, ID. Sagebrush steppe is the dominant ecosystem with flora and fauna typical to the northern Great Basin and the Columbia Plateau. Much of the area has been protected from human disturbance over the past 50 years and substantial long-term information about the vegetation has been collected. Recently, vegetation and fire data have been mapped using GIS. Parts of the site are grazed periodically and a great deal of cropland borders the site. In addition, the local NOAA division (Field Research Division) has an eddy flux tower in operation within a mature sagebrush stand at the site (Clawson et al., 2001).

\section{BENEFITS}

Determining the carbon and energy balance and their variations across a landscape of different land-uses, will provide a better understanding of these processes in North American deserts, provide better understanding of the factors that determine $\mathrm{CO}_{2}$ atmospheric concentrations and thereby reduce uncertainties in model projections, and provide a more comprehensive measurement $\mathrm{CO}_{2}$ for this region. The long-term monitoring of carbon and energy fluxes will provide a more definitive evaluation of longterm changes in the carbon and energy balance.

\section{REFERENCES}

Angell, R. F., Svejcar, T., Bates, J., Saliendra, N. Z., Johnson, D. A. 2001. Bowen Ratio and Closed Chamber Carbon Dioxide flux Measurements over Sagebrush Steppe Vegetation. Ag. And For. Meteorology 108:153-161.

Clawson, K. L., Johnson, D. A., Saliendra, N. Z. 2001. Initial comparisons of fluxes from Bowen Ratio and Eddy Correlation Instrumentation over a Sagebrush Steppe Ecosystem, pp. 72-73. Preprint, 11th Symposium on Meteorological Observations and Instrumentation, Jan. 14-18, Albuquerque NM, American Meteorological Society.

Hipps, L. 2002. Utah State University, Dept. Plants, Soils and Biometeorology, Logan, UT (435 $797-$ 2009).

Jackson, R. B., Carpenter, S. R., Dahm, C. N., McKnight, D. M., Naiman, R. J., Postel, S. L., Running, S. W. 2001. Water In a Changing World. Ecological Applications 11(4):1027-1045. 
MacDonald, A. E. 2001. The Wild Card in the Climate Change Debate. Issues in Science and Technology online, Summer 2001 (http://www.nap.edu/issues/).

Noss, R. F., LaRoe III, E. T., Scott, J. M. 1995. Endangered Ecosystems of the United States: A Preliminary Assessment of Loss and Degradation. Biological Service Report 28, U.S. Dept. of the Interior, National Biological Service, Washington, D.C., 58 pp. Available: http://biology.usgs.gov/pubs/ecosys.htm.

Parson, E. A., P. W. Mote, A. Hamlet, N. Mantua, A. Snover, W. Keeton, E. Miles, D. Canning, K. G. Ideker. 2001. Potential Consequences of Climate Variability and Change for the Pacific Northwest, pp. 247-280. In National Assessment Synthesis Team, Climate change Impacts on the United States: The Potential Consequences of Climate Variability and Change, Report for the US Global change Research Program, Cambridge University Press, Cambridge UK, 620 pp.

U.S. Climate Change Research Initiative. 2001. U.S. Climate Change Research Initiative: Survey of Research Strategies to Reduce Scientific Uncertainties (http://www.usgcrp.gov/usgcrp/Library/CCRIreport-aug2001/CCRIreport-aug2001a.htm).

West, N. E. 1983a. Great Basin-Colorado Plateau Sagebrush Semi-desert, pp. 331-349. In Temperate Deserts and Semi-deserts. Ecosystems of the World, fifth edition, Elsevier, Amsterdam, The Netherlands. 